\title{
Cloning and expression of truncated ORF2 as a vaccine candidate against hepatitis E virus
}

\author{
Dibya Rani $^{1} \cdot$ Rahul Saxena $^{1} \cdot$ Baibaswata Nayak $^{2} \cdot$ Sudha Srivastava $^{1}$ (i)
}

Received: 1 May 2018 / Accepted: 10 September 2018 / Published online: 15 September 2018

๑) Springer-Verlag GmbH Germany, part of Springer Nature 2018

\begin{abstract}
Hepatitis E virus infection is responsible for acute viral hepatitis and associated with high mortality and still birth in pregnant women in developing countries. We report expression of truncated forms of HEV ORF2 as potential vaccine candidates for nanoparticle-based delivery. These two truncated ORF2 proteins ( $54 \mathrm{kDa}$ and $26 \mathrm{kDa}$ ) have been reported to be highly immunogenic and can be used as nanoparticle-based vaccine candidate. The bacterial expressed protein was purified by affinity chromatography and further confirmed by western blot using anti-HEV antibody. The chitosan nanoemulsion was synthesized using ultrasonic waves. The nanoparticle size was found to be 120-160 nm and the entrapment efficiency of purified truncated ORF2 proteins within these nanoparticles was 70\% (26 kDa) and 59\% (54 kDa). In cell cytotoxicity analysis, $100 \mu \mathrm{g} / \mathrm{mL}$ nanoemulsion was found suitable for cell viability in both HeLa and THP1 cell lines. Release kinetics of encapsulated proteins at physiological $\mathrm{pH} 7.4$ showed $26-59 \%$ and $9.7-40 \%$ release of $26 \mathrm{kDa}$ and $54 \mathrm{kDa}$ protein within $1 \mathrm{~h}$ that gradually increased with time $(48 \mathrm{~h})$. Encapsulated proteins were found to be unstable at $\mathrm{pH} 1.2$.
\end{abstract}

Keywords Chitosan $\cdot$ Nanoemulsion $\cdot$ Hepatitis E virus $\cdot$ Truncated ORF2

\section{Introduction}

Hepatitis $\mathrm{E}$ virus (HEV) infection is the major cause of acute viral hepatitis with 20 million new infection cases 70,000 deaths and 3000 stillbirths worldwide (Rein et al. 2012). HEV infection is self-limiting and resolves within 4 weeks. In pregnant women, HEV-related mortality rate is very high (25\%) (Khuroo et al. 1981).This calls for due attention and need for vaccine development. Due to lack of cell culture system to grow HEV, it is not possible to develop traditional live attenuated or killed vaccine, so we rely either on protein or DNA for vaccine development.

HEV is single stranded, positive sense RNA virus with a genome size of approximately $7.2 \mathrm{~kb}$ (Yamashita et al. 2009). HEV genome contains four open reading frames (ORFs), of which ORF2 encodes $72 \mathrm{kDa}$ capsid protein which is immunogenic in nature (Tam et al. 1991; Nair et al.

Sudha Srivastava

sudha.srivastava@jiit.ac.in

1 Department of Biotechnology, Jaypee Institute of Information Technology, Noida, UP 201309, India

2 Department of Gastroenterology, All India Institute of Medical Sciences, Ansari Nagar, New Delhi 110029, India
2016). Various truncated forms of ORF2 encoded proteins have been used as vaccine candidates (Purdy et al. 1992; Zhang et al. 2001; Li et al. 2004, 2005; Purcell et al. 2003; Arankalle et al. 2009; Huang et al. 2009). In all these studies, FDA approved-alum was used as adjuvant to increase the immunogenicity with exception of lipo-NE-DP (aa 458-607) and pE2 (aa 394-604) that employed liposomes and Freund's adjuvant. In addition to these, chitosan and polycaprolactone nanoparticles have also been used as adjuvant for other vaccines (Jesus et al. 2017). However, only two vaccines HEV $239(26 \mathrm{kDa})$ and $56 \mathrm{kDa}$ have progressed to human clinical trials. The larger ORF2 fragment encoding amino acid (aa) $112-607(54 \mathrm{kDa})$ retains all the properties of ORF2 and also sufficient to form VLPs when expressed in baculovirus vector (Li et al. 1997, 2005), whereas the smaller ORF2 fragment encoding $368-607$ aa (26 kDa) is highly immunogenic and sufficient to elicit immune response ( $\mathrm{Li}$ et al. 2005). The HEV 239 (termed Hecolin ${ }^{\circledR}$ ), is licensed for use in China (Taherkhani and Farshadpour 2015).

We have selected these two fragments for nanoparticlebased vaccine development. In this study, chitosan nanoemulsion synthesis, electron microscopy, uptake and release of candidate vaccine in different physiological $\mathrm{pH}$ and at different time points were studied. The suitable dose of 
chitosan nanoemulsion for toxicity was analyzed by cell viability assay.

\section{Materials and methods}

\section{Cloning of truncated HEV ORF2}

The ORF2 region (GenBank accession no. AF444003.1) of HEV genotype 1 was commercially synthesized. Amplification of truncated 112-606aa and 368-606aa regions was carried out using primers (NdeHEV112aa-334F:ggCAT ATGgcggtcgetccggcceatgac, NdeI-HEV368aa-1102F: ggCATATGatagcgcttaccetgtttaac and XhoI-ORF2-606aa1821R:ccCTCGAGcacagagtggggggctaaaac). The PCR amplified products were cloned in pET30b vector at NdeIXhoI site by directional cloning. The ligation products were transformed in DH5 $\alpha$ E. coli competent cells and positive clones were screened by RE digestion and sequence confirmed.

\section{Expression and purification of recombinant protein}

pET30b-ORF2 was transformed into BL21 (DE3) E. coli competent cells followed by inoculation of single colony in Luria Bertaini (LB) media at $37{ }^{\circ} \mathrm{C}$ with stirring at 180 rpm overnight. This was followed by subculturing in fresh LB and allowed to grow until absorbance (OD at $600 \mathrm{~nm}$ ) reaches $0.4-0.8$ before induction with $0.2 \mathrm{mM}$ IPTGfor $2.5 \mathrm{~h}$ at $37{ }^{\circ} \mathrm{C}$. The induced bacterial culture was centrifuged at $8000 \mathrm{rpm}$ for $10 \mathrm{~min}$ at $4{ }^{\circ} \mathrm{C}$. The expression of recombinant protein was analyzed on $10 \%$ SDS-PAGE.

The bacterial pellets were resuspended in lysis buffer (50 mM NaH${ }_{2} \mathrm{PO}_{4} \mathrm{pH} 8.0,300 \mathrm{mM} \mathrm{NaCl}, 2 \mathrm{mM}$ $\beta$-mercaptoethanol, $0.2 \%$ sarkosyl) and sonicated for $2 \mathrm{~min}$ with pulse cycle of $10 \mathrm{~s}$ on and $20 \mathrm{~s}$ off. After centrifugal separation, supernatant containing recombinant proteins were purified using Ni-NTA spin columns from G-Biosciences following product manual. The eluted proteins were analyzed on $10 \%$ SDS-PAGE and confirmed by western blot using anti-HEV-positive serum and goat anti-human IgG/ HRP and 3,3'-diaminobenzidine (DAB) as chromophore.

\section{Synthesis of chitosan nanoemulsion}

An $(\mathrm{o} / \mathrm{w})$ emulsion of chitosan was prepared by addition of $0.1 \%$ chitosan solution into oil phase containing olive oil and surfactant (PluronicF-127) followed by dropwise addition of cross-linking agent glutaraldehyde under continuous ultrasonication (Akbuğa and Durmaz 1994). Synthesized o/w nanoemulsion was observed under optical microscope $100 \times$ and transmission electron microscope (TEM).

\section{Toxicity analysis of chitosan nanoemulsion}

HeLa and THP1 cells were seeded in 96-well plates at cell density of $1 \times 10^{3}$ in each well and grown to subconfluent $(70 \%$ confluency) stage. The chitosan nanoemulsion (CNE) of concentrations 25, 50, 100, 150, 175, 200, 250, and $275 \mu \mathrm{g} / \mathrm{mL}$ were added to these cells and incubated for $24 \mathrm{~h}$. MTT assay was performed to test toxicity of CNE on HeLa and THP1 cell lines (Meerloo et al. 2011). Percentage of viable cells were evaluated using formula:

$\%$ Cell viability $=\left(\mathrm{Abs}_{\text {sample }} / \mathrm{Abs}_{\text {control }}\right) \times 100$.

\section{Protein release kinetics and stability analysis}

Twenty microgram $(\mu \mathrm{g})$ of the purified protein was incubated with $100 \mu \mathrm{g} / \mathrm{mL}$ of $\mathrm{CNE}$ for overnight at $4{ }^{\circ} \mathrm{C}$. The entrapment efficiency was evaluated by quantifying percentage of protein remaining in supernatant after centrifugation of protein-loaded CNE (CNP) at $9000 \mathrm{rpm}$ for $15 \mathrm{~min}$. Finally, CNP was incubated in $10 \mathrm{~mL}$ of simulated intestinal fluid (SIF) pH (6.8) $\left(\mathrm{KH}_{2} \mathrm{PO}_{4} 6.8 \mathrm{~g} / \mathrm{L}, \mathrm{NaOH} 0.89 \mathrm{~g} / \mathrm{L}\right)$, phosphate buffer (PB), $\mathrm{pH}$ (7.4) $\left(\mathrm{KH}_{2} \mathrm{PO}_{4} 3.4 \mathrm{~g} / \mathrm{L}, \mathrm{Na}_{2} \mathrm{HPO}_{4}\right.$ $3.5 \mathrm{~g} / \mathrm{L})$ and simulated gastric fluid (SGF) $\mathrm{pH}(1.2)[\mathrm{NaCl}$ $2.0 \mathrm{~g} / \mathrm{L}, \mathrm{HCl}$ (concentrated) $7.0 \mathrm{~mL} / \mathrm{L}]$. This was followed by centrifugation at $9000 \mathrm{rpm}$ for $15 \mathrm{~min}$ at $4{ }^{\circ} \mathrm{C}$ and protein estimation in supernatant at after 1, 3, 5, 24 and $48 \mathrm{~h}$.

\section{Results and discussion}

The truncated ORF2 region was PCR amplified using genespecific primers and was observed as $719 \mathrm{bp}$ and $1487 \mathrm{bp}$ band on $1.5 \%$ agarose gel. The gel purified PCR products were further subcloned in bacterial expression vector pET30b at NdeI and XhoI site. The colonies obtained after transformation were screened for positive clone by RE digestion analysis.

\section{Protein expression and purification-truncated ORF2}

The recombinant clones were expressed in BL21 (DE3) E. coli competent cells by induction with $0.2 \mathrm{mM}$ IPTG at $37{ }^{\circ} \mathrm{C}$ for $2.5 \mathrm{~h}$. The expressed proteins were analyzed on $10 \%$ SDS-PAGE. Figure 1a shows overexpression of induced proteins of $26 \mathrm{kDa}$ and $54 \mathrm{kDa}$ in Lane 1 and Lane 4 , respectively, as opposed to the uninduced culture pellet in Lane 7. After lysis, approximately $55 \%$ of $26 \mathrm{kDa}$ (Lane 3) and $80 \%$ of $54 \mathrm{kDa}$ (Lane 6) proteins are solubilized while remaining proteins (Lane 2,5 ) remains in insoluble fraction. Figure $1 \mathrm{~b}$ shows Ni-NTA purified eluted fractions of both $54 \mathrm{kDa}$ (Lane 1-3) and $26 \mathrm{kDa}$ (Lane 8-9) proteins with 

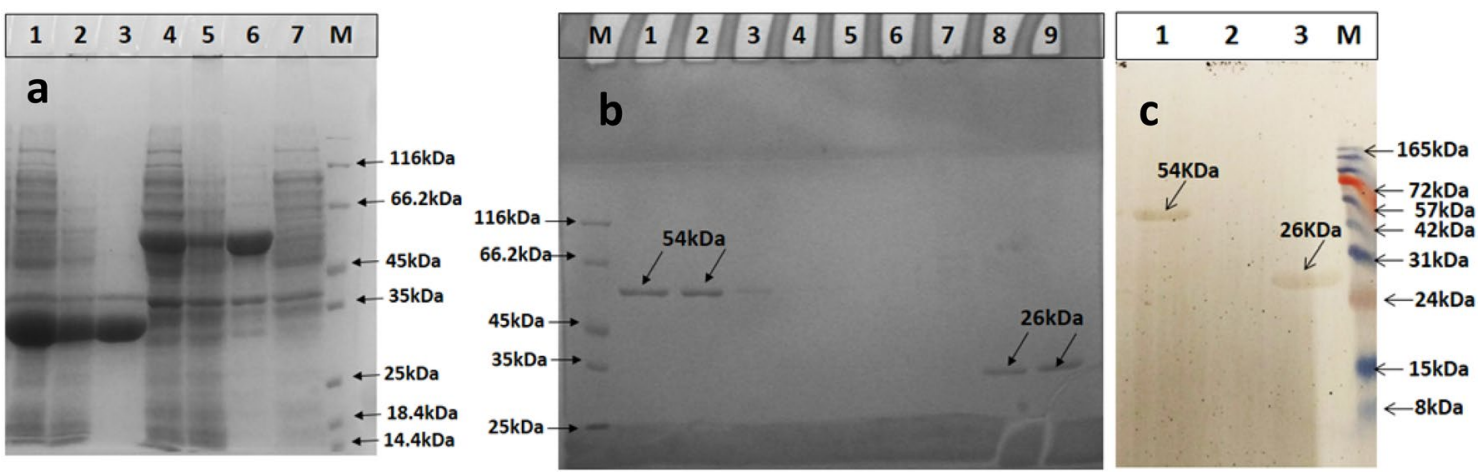

Fig. 1 a Analysis of truncated ORF2 protein expression on $10 \%$ SDS-PAGE, Lane 1, 4: induced sample of $26 \mathrm{kDa}$ and $54 \mathrm{kDa}$, Lane 2, 5: insoluble and Lane 3, 6 soluble fraction of $26 \mathrm{kDa}$ and $54 \mathrm{kDa}$ proteins after lysis, Lane 7: uninduced sample, Lane M: protein Marker; b Ni-NTA purification fractions on 10\% SDS-PAGE with Lane M: protein marker; Lane 1-3: $54 \mathrm{kDa}$ eluted fractions, Lane
4-6: third, fourth and fifth washing sample; Lane 7: flow through; Lane 8, 9: $26 \mathrm{kDa}$ eluted fraction; c Western blot image-Lane M: prestained protein molecular weight marker, Lane 1 and Lane 3: $54 \mathrm{kDa}$ and $26 \mathrm{kDa}$ purified proteinsand Lane 2: negative control (uninduced sample) flowthrough in Lane 7 and final washing step sample in Lane 4-6 while Lane M shows marker protein. Finally, purified proteins were confirmed by western blot using HEV-positive human sera. Figure 1c shows $54 \mathrm{kDa}$ and $26 \mathrm{kDa}$ browncolored band developed in Lane 1 and Lane 3, respectively, after incubation with HRP-tagged secondary antibody and exposure with DAB while no band was observed in uninduced sample (Lane 2). Lane $\mathbf{M}$ shows prestained protein molecular weight marker.

\section{Nanomaterial cytotoxicity, protein entrapment and release analysis}

Chitosan nanoemulsion synthesized using ultrasonic waves were characterized using optical microscopy and transmission electron microscopy (TEM). Optical image of chitosan nanoemulsion (Fig. 2a) shows spherical particles. Further characterization using TEM shows size of CNE to be 120-160 nm (Fig. 2b).

Dose optimization and toxicity analysis of nanoemulsion was evaluated for on HeLa and THP1 cell lines. Cells subcultured in a 96-well plate at $70 \%$ confluency, were treated with different concentrations of chitosan nanoemulsions (in triplicate) for viability testing by MTT assay. In MTT assay, optimum cell viability (>90\%) was observed (Fig. 2c) $100 \mu \mathrm{g} / \mathrm{mL}$ of CNE-treated cells. The cell viability further reduced to $80 \%$ beyond $150 \mu \mathrm{g} / \mathrm{mL}$ and remains only $50 \%$ at $275 \mu \mathrm{g} / \mathrm{mL}$ of CNE treatment. Further, toxicity of particles was also evaluated on the in vitro model for immune modulation, i.e., THP1 cell lines. THP1 cells treated with $50 \mu \mathrm{g} / \mathrm{mL}$ of CNE shows $85 \%$ of viable cells, while further increase in CNE upto $275 \mu \mathrm{g} / \mathrm{mL}$ shows $75 \%$ of viable cells. Hence, based on the results from both cell lines, $100 \mu \mathrm{g} / \mathrm{mL}$ concentration of nanoparticles for in vivo studies may be considered for less toxicity.

Protein entrapment efficiency was calculated by incubating the $20 \mu \mathrm{g}$ of each protein with $100 \mu \mathrm{g}$ of CNE overnight in separate tubes. The suspensions were centrifuged and supernatant evaluated for the amount of protein. Results showed $70 \%$ and $59 \%$ entrapment of $26 \mathrm{kDa}$ and $54 \mathrm{kDa}$ proteins. Finally, protein release kinetics and stability analysis under different $\mathrm{pH}$ conditions was evaluated in simulated intestinal fluid (SIF) pH 6.8, phosphate buffer (PB) pH 7.4 and simulated gastric fluid (SGF), pH1.2 for vaccine studies. Figure $2 \mathrm{~d}$ shows an initial quick release of $26 \%$ of $26 \mathrm{kDa}$, while only $9.7 \%$ of $54 \mathrm{kDa}$ protein. A gradual increase upto $59 \%(26 \mathrm{kDa})$ and $40 \%$ (54 kDa) protein release upto $48 \mathrm{~h}$ was observed. However, in SIF after initial protein release of $100 \%$ protein, the protein percentage gradually decreases to less than $30 \%$ suggestive of instability. While in SGF, no protein peak was observed indicative of either no release or complete degradation of protein within $1 \mathrm{~h}$.

\section{Conclusion}

In the present study, two immunogenic fragments of HEV ORF2 were cloned and expressed proteins of $26 \mathrm{kDa}$ and $54 \mathrm{kDa}$ were purified. CNE of 120-160 nm size negligible toxicity upto $150 \mu \mathrm{g} / \mathrm{mL}$ with $90 \%$ cell viability. Protein entrapment, release and stability analysis showed instability at $\mathrm{pH} 1.2$, thus eliminating oral vaccine possibility.The capsid fragment used for bacterial expression belongs to HEV genotype 1 . This candidate vaccine can possibly cross protect to other genotype as this region share amino acid homology among genotypes. The efficient delivery in host and antibody production will be checked in our future study.

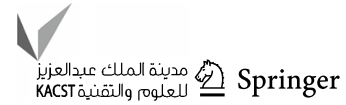



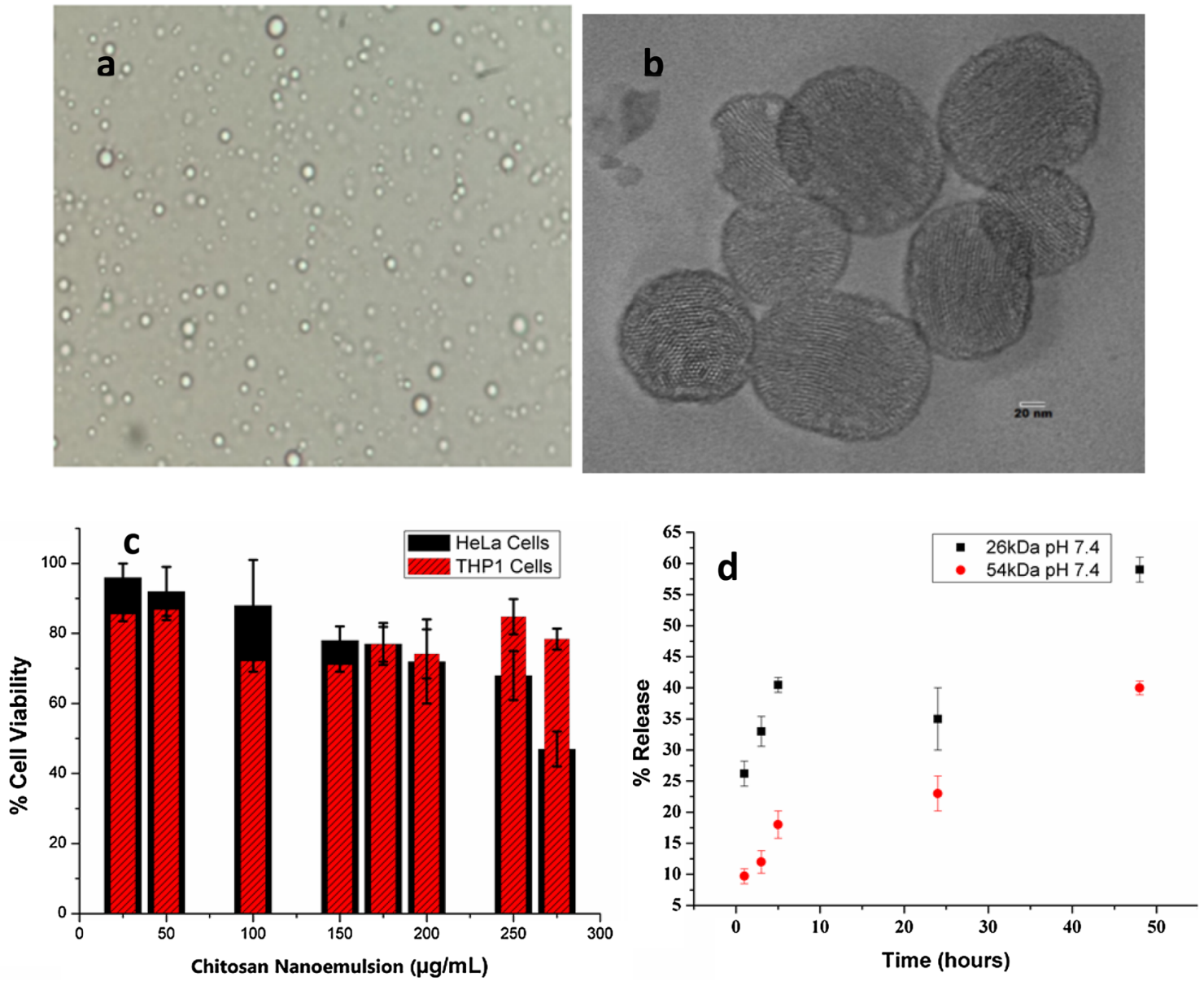

Fig. 2 a Optical microscopic image of o/w chitosan nanoemulsion at $\times 100$. b Transmission electron micrograph of chitosan nanoemulsion at $\times 50,000$, $\mathbf{c}$ percentage viability of HeLa cells (black bars) and

Acknowledgements Authors SS, DR and RS are thankful to Jaypee Institute of Information Technology and BN is thankful to AIIMS for the support for carrying out research work. DR and RS are also thankful to DST-INSPIRE (IF 150454 and IF 150897), Government of India for the fellowship and contingency Grant

\section{Compliance with ethical standards}

Conflict of interest All authors hereby declare that there is no conflict of interest.

\section{References}

Akbuğa J, Durmaz G (1994) Preparation and evaluation of cross-linked chitosan microspheres containing furosemide. Int J Pharm. https ://doi.org/10.1016/0378-5173(94)90344-1

Arankalle VA, Lole KS, Deshmukh TM et al (2009) Challenge studies in Rhesus monkeys immunized with candidate hepatitis $\mathrm{E}$ vaccines: DNA, DNA-prime-protein-boost and DNA-protein encapsulated in liposomes. Vaccine. https://doi.org/10.1016/j.vacci ne.2008.11.097

THP1 cells (red bars) on treatment with varying concentration of chitosan nanoemulsion. d Percent protein released with time in SIF, SGF and PB

Huang WJ, Zhang HY, Harrison TJ et al (2009) Immunogenicity and protective efficacy in rhesus monkeys of a recombinant ORF2 protein from hepatitis E virus genotype 4. Arch Virol. https://doi. org/10.1007/s00705-009-0335-7

Jesus S, Soares E, Borchard G, Borges O (2017) Poly-€-caprolactone/ chitosan nanoparticles provide strong adjuvant effect for hepatitis B antigen. Nanomedicine. https://doi.org/10.2217/nnm-2017-0138

Khuroo MS, Teli MR, Skidmore S et al (1981) Incidence and severity of viral hepatitis in pregnancy. Am J Med. https://doi. org/10.1016/0002-9343(81)90758-0

Li TC, Yamakawa Y, Suzuki K et al (1997) Expression and selfassembly of empty virus-like particles of hepatitis E virus. J Virol 71(10):7207-7213

Li TC, Suzaki Y, Ami Y et al (2004) Protection of cynomolgus monkeys against $\mathrm{HEV}$ infection by oral administration of recombinant Hepatitis E virus-like particles. Vaccine. https://doi.org/10.1016/j. vaccine.2003.08.004

Li SW, Zhang J, Li YM et al (2005) A bacterially expressed particulate hepatitis $\mathrm{E}$ vaccine: antigenicity, immunogenicity and protectivity on primates. Vaccine. https://doi.org/10.1016/j.vacci ne.2004.11.064

van Meerloo J, Kaspers GJL, Cloos J (2011) Cell sensitivity assay: the MTT assay. In: Cree I (ed) Cancer cell culture: methods and protocols. Methods in molecular biology, vol 731. Humana 
Press, Totowa, pp 237-245. https://doi.org/10.1007/978-1-61779 $-080-5 \_20$

Nair VP, Anang S, Subramani C et al (2016) Endoplasmic reticulum stress induced synthesis of a novel Viral factor mediates efficient replication of genotype-1 hepatitis E virus. PLoS Pathog. https:// doi.org/10.1371/journal.ppat.1005521

Purcell RH, Nguyen H, Shapiro M et al (2003) Pre-clinical immunogenicity and efficacy trial of a recombinant hepatitis $\mathrm{E}$ vaccine. Vaccine. https://doi.org/10.1016/S0264-410X(03)00100-2

Purdy MA, McCaustland KA, Krawczynski K et al (1992) Expression of a hepatitis $\mathrm{E}$ virus (HEV)-trpE fusion protein containing epitopes recognized by antibodies in sera from human cases and experimentally infected primates. Arch Virol 123:335-349

Rein DB, Stevens GA, Theaker J et al (2012) The global burden of hepatitis E virus genotypes 1 and 2 in 2005. Hepatology. https:// doi.org/10.1002/hep. 25505
Taherkhani R, Farshadpour F (2015) A new strategy for development of hepatitis E vaccine: epitope-based vaccines. Pathog Infect Dis. https://doi.org/10.14800/pid.933

Tam AW, Smith MM, Guerra ME et al (1991) Hepatitis E virus (HEV): molecular cloning and sequencing of the full-length viral genome. Virology. https://doi.org/10.1016/0042-6822(91)90760-9

Yamashita T, Mori Y, Miyazaki N et al (2009) Biological and immunological characteristics of hepatitis E virus-like particles based on the crystal structure. Proc Natl Acad Sci USA. https://doi. org/10.1073/pnas.0903699106

Zhang M, Emerson SU, Nguyen H et al (2001) Immunogenicity and protective efficacy of a vaccine prepared from $53 \mathrm{kDa}$ truncated hepatitis $\mathrm{E}$ virus capsid protein expressed in insect cells. Vaccine. https://doi.org/10.1016/S0264-410X(01)00399-1 